\title{
The SeXual Citizen
}

Ngaire Naffine*

This introduction to the Sexuality and Citizenship Special Issue considers the concept of the sexual citizen. It also examines and draws together the themes of the papers that formed part of the symposium held on 28 and 29 November 2005.

Modern Anglian law ${ }^{1}$ is deeply ambivalent about our legal nature and significance as sexed and sexual persons. Our lives as sexual men and women are still explicitly regulated by family law which, as Graeme Austin reminds us, "fits awkwardly with historical narratives that portray the 'movement' in progressive societies as being 'from status to contract'."2 Family law seems distinctly unmodern in that it is about sex and affect. It is about sexual relations based on status and affection. Family law "is as much concerned with issues arising from these loving connections with others as it is with mediating deliberative transactions between people in family relationships, and status continues to be among family law's principal concerns." 3

And yet family law is also at least quasi-contractual in nature. It is about that highly particular and old-fashioned standard "contract", the marriage contract: ${ }^{4}$ the public statement, given legal recognition, of our sexed and sexual relations which must take a very specific, not chosen, form. Traditionally, the marriage contract has been characterised in a highly exclusive and patriarchal manner as the union of one man and one woman, ${ }^{5}$ with the man once explicitly the head of the

* Professor of Law, University of Adelaide.

1 This is law in the English tradition, thus dubbed by Peter Cane in: Peter Cane Responsibility in Law and Morality (Hart, Oxford, 2002) 7.

2 Graeme W Austin "Essay: Family Law and Civil Union Partnerships - Status, Contract and Access to Symbols" (2006) 37 VUWLR 183, 183 (footnote omitted).

3 Austin, above n 2, 185.

4 See Carole Pateman The Sexual Contract (Stanford University Press, California, 1988) for an extended analysis of the patriarchal basis of the marriage contract.

$5 \quad$ Hyde $v$ Hyde and Woodmansee [1861-1873] All ER 175, 178 Wilde JO provides the classical common law definition of marriage as the union of "a man and a woman". 
family unit. It has positively precluded the formation of legally-sanctioned sexual relations of choice.

By contrast, modern legal relations are more typically understood and affirmed as relations at a physical distance, transacted between individuals (not members of a sex or sexual grouping), who relate to one another in a contractual manner, out of personal choice, on their own terms and usually for rational economic purposes. The creation story of our modern law, as told by Sir Henry Maine, ${ }^{6}$ is about freeing the individual from the group and the emergence of the contractual individual from relations and statuses not based on choice. Taking a broad historical sweep, from the medieval to the modern period, Maine described a shift from a hierarchical or vertical society, based on customary status, to an equal or horizontal society, based on personally-chosen contracts. Choice manifested through the use of contract, and exercised at a physical and social distance, has come to exemplify modern legal relations: thus it is that we moderns are meant to give expression to our human freedoms. ${ }^{7}$ Or as Lawrence Friedman has put it: "Modern law presupposes a society of freestanding, autonomous individuals." 8

But sex and affection have never gone away and nor has the desire to place those sexual and affectionate relations on a public footing: hence the institutions of family law. The enduring problem is that the law of sex and affection has not been modernised, and we still do not know how to think of sex and sexuality in a liberal egalitarian manner. Certainly we have yet to reconcile the modern liberal understanding of ourselves - as free, equal, rational choosing individual agents with our sexed, sexual, emotional and embodied lives.

Our legal model for thinking about the loving and physical side of life remains deeply orthodox and patriarchal. According to this model, sex should take place only between the sexes and in anticipation of a family. We retain, in modern Anglian law, an idea of marriage as an institution for accommodating and regulating sexual relations between men and women, essentially for reproductive purposes, and sex which lacks this purpose is still inherently suspect. ${ }^{9}$ And there remains a squeamishness, even a Victorian disgust, within parts of the legal community about sex which takes any other form. As Edward Clark observes of the New Zealand judiciary, after his

6 Henry Maine Ancient Law (Oxford University Press, London, 1959).

7 This is the story of contract starkly told but it remains an influential one.

8 Lawrence Friedman "Is there a Modern Legal Culture?" (1994) 7 Ratio Juris 117, 125.

9 One of the most eminent and vocal legal exponents of this view of sexuality is John Finnis who has openly criticised homosexual relations. See for example "Law, Morality and 'Sexual Orientation'" in John Corvino (ed) Same Sex: Debating the Ethics, Science and Culture of Homosexuality (Lanham-Boulder, New York, 1997). 
extensive inquiry into modern judicial attitudes towards homosexuality, there is still a pervasive view that sexual relations between men are undesirable and deviant, even "unspeakable". ${ }^{10}$

Modern legal thinking about sex and sexuality still bears a close resemblance to that described by Kant in The Metaphysics of Morals. ${ }^{11}$ Here Kant distinguished between man "as a sensible being, that is, as man (a member of one of the animal species), and ... as an intelligible being."12 For Kant, man was most importantly and characteristically an intelligible being and it was from his capacity to reason, his life of the mind, of the intellect, that he attained his dignity and his autonomy, his very pride in being human.

But Kant also conceded the animal side of life. He went on to deal at length with the nature and duties of man "as an animal being". ${ }^{13}$ Sensible or animal man's first duty to himself was that of selfpreservation. His second duty was not to defile himself by lust. To Kant it was wrong for man to "make use of another person to get this [animal] pleasure apart from a special limitation by a contract establishing the right, by which two persons put each other under obligation." 14 Here he was referring to the marriage contract between a man and a woman that had the legitimate sexual purpose of procreation.

The only rightful "bodily union" was heterosexual and within the confines of marriage. ${ }^{15}$ The vital respect that Kant required man to show man demanded that men "keep themselves at a distance from one another". ${ }^{16}$ Further, it was important to take care of oneself as a physical being; he referred to "taking care of one's body, but not to the point of effeminacy."17

Male effeminacy, to Kant, was a form of personal degradation. The man of dignity controlled and channelled his physical urges, kept them within the confines of marriage, where they could be given appropriate manly expression; he retained a physical distance from other men and certainly avoided effeminacy. This image of the man brought down and rendered repulsive by effeminacy, by

10 Edward Clark "The Construction of Homosexuality in New Zealand Judicial Writing" (2006) 37 VUWLR $199,205$.

11 Immanuel Kant The Metaphysics of Morals (Cambridge University Press, Cambridge, 1991).

12 Kant, above n 11, 215

13 Kant, above n 11, 218.

14 Kant, above n 11, 220.

15 Kant, above n 11, 221.

16 Kant, above n 11, 244.

17 Kant, above n 11, 246. 
his unnatural urges, is still with us. Implicitly, it forms the basis of "the defence of provocation in cases of unwanted homosexual advances", described by Elisabeth McDonald. ${ }^{18}$

For this very reason, according to McDonald, the provocation defence should be disallowed in such circumstances because it can only be based on a hatred of homosexuals. The very existence of the defence implies a sympathetic legal understanding of those men who find homosexual men so disgusting and alarming that they are provoked to kill by such an approach. McDonald finds support for her argument against the homosexual advance defence in a new provision of the Sentencing Act 2000, which allows sentencing judges to treat crimes animated by hostility to those of a particular sexual orientation as aggravated, as more serious, rather than as excused. The continuing "operation of the defence", she says, "reinforces the vulnerability of gay men as 'dangerous outlaws"' and necessarily condones homophobia. ${ }^{19}$ It also indicates the deep legal ambivalence about homophobia which can now function "both as an aggravating and a mitigating factor in New Zealand homicide cases." $^{20}$

Dean Knight asks us to consider still another way in which modern Anglian law remains deeply ambivalent about homosexuality. ${ }^{21} \mathrm{He}$ reflects on whether unwanted imputations of gayness are defamatory. The test in defamation actions is whether "the right-thinking person" would find them defamatory. This fictional character bears an interesting resemblance to the ordinary person of the provocation defence. Both are legal invocations of a standard imaginary character that is meant, somehow, to stand in for the community at large. Through this legal device, the community, with its supposed attitudes and/or powers of control, is imaginatively brought into a court of law and the fact-finder must engage in a thought experiment: what would the community think or do in this instance? The jurisprudence reveals that right-thinking persons once regarded an imputation of homosexuality as a slur on character but these days they should harbour no such discriminatory thoughts. After all there are now anti-discrimination laws which tell them that such attitudes are unacceptable.

But as all the authors in this issue agree, homosexuality has not been brought fully into public life and acquired positive connotations. At best, there is a grudging tolerance, rather than an open embrace or celebration of it. The new Civil Union Act 2004 does much to extend the conventional rights of marriage to gay couples, but it still does not permit them to marry. As Nan Seuffert explains: "It allows the extension of most of the rights and responsibilities of marriage, and the

18 Elisabeth McDonald "No Straight Answer: Homophobia as Both an Aggravating and Mitigating Factor in New Zealand Homicide Cases" (2006) 37 VUWLR 223, 225.

19 McDonald, above n 18, 234 (footnote omitted).

20 McDonald, above n 18, 223.

21 Dean Knight "'I'm Not Gay - Not That There's Anything Wrong with That!': Are Unwanted Imputations of Gayness Defamatory?" (2006) 37 VUWLR 249. 
control and normalization of marriage, to same sex couples at the same time as it creates a two-tier system." 22 Heterosexual marriage remains "the gold standard". ${ }^{23}$ The debates which preceded the new law contained few "positive statements about gay and lesbian sexuality or sexual intimacy". ${ }^{24}$ Gay partnerships were to be permitted, not applauded. One would not want to think too hard about the nature of sexual intimacy between persons of the same sex. Certainly one would not want to reshape the very idea of a New Zealander: to introduce a new "sexual citizen". This would be going too far.

With her reference to "sexual citizenship", Seuffert returns us to a problem that seems to bedevil the public recognition of our private sexual lives in a manner which is compatible with our personal and public freedom and equality. She puts the problem to us squarely: ${ }^{25}$

Citizenship has traditionally been figured as access to a set of static rights as a result of membership within a nation. ... . In this conceptualization, citizenship concerns the exercise of rights in the public realm. It follows that the idea of 'sexual citizenship' is a contradiction in terms; sexual activity is part of the private realm, while citizenship happens in the public sphere.

How are we to blend these two parts of our lives - as public citizens and private sexual beings? Isn't our sexual life necessarily a private matter unrelated to our public civic lives and somehow natural in form? The way that the story of contract, and the making of modern law, has been told certainly encourages us to think of family/sexual life as private and pre-legal. It is regarded as that part of life and law which has not moved fully into the modern world of freely-chosen contracts; which remains almost medieval in nature in that it is "mediated by principles of love and duty ... . It [is] a family-oriented, status-dependent form of association". ${ }^{26}$ There seems therefore to be an implicit tension between the idea of the private sexual and loving person - the person who wishes to be defined at least partly by their loving and sexual associations - and the modern public individual of the public square, exercising their public freedoms. Love and sex are still thought to belong in the family and the family remains essentially a pre-modern institution with a patriarchal form. And there is also a natural form to the family, in this view. There is a biological woman who is a wife (to a man) and mother, a biological man who is a husband (to a woman) and father and these identities are fixed, essential and distinct.

22 Nan Seuffert "Sexual Citizenship and the Civil Union Act 2004" (2006) 37 VUWLR 281, 305.

Seuffert, above n 22, 283 (footnote omitted).

24 Seuffert, above n 22, 299.

25 Seuffert, above n 22, 289-290 (footnote omitted).

26 Kevin Gray and P D Symes Real Property and Real People: Principles of Land Law (Butterworths, London, 1981) 15. 
Still quite alien to modern legal thinking is the sort of view of paternity or maternity espoused by Paula Baron, in which a person of either sex could play the role of father or mother: in which traditionally sexed roles are not absolutely linked to a particular natural sex. ${ }^{27}$ Instead our understanding of sex, sexuality and parenting remain privatised and naturalised. A man is a father and a husband; a woman is a wife and a mother. Indeed, a strong Christian ethic, with its idea of a natural and sanctified family order, even now pervades our understanding of what it is to marry and found a family. The debates about the Civil Union Act 2004 made this only too clear.

As a consequence the very idea of "sexual citizenship", as Seuffert puts it, appears to be "a contradiction in terms". ${ }^{28}$ Citizenship has come to be understood in terms of the rights that we exercise in the public realm as unencumbered members of a nation. It is about the rights of public individuals within a polity. But sexual activity is still thought of as part of the private, natural and intimate sphere of life, not a part of the political and legally-regulated realm.

This, of course, is not the truth of it and we are deceived if we accept that the heterosexual family has ever been natural, innate and so outside of the public legal order. The regulation of marriage and the legal and economic benefits that accrue as a consequence are fully public phenomena. They shape our public lives and help to form our public identities. ${ }^{29}$ Culturally, too, the heterosexual person is permitted to give full public expression to the fact that they bed down with a person of the other sex, have children, and love and care for all of them. Though the family has retained many of its feudal forms, and is still talked of as the private, natural and even sacred sphere of life, heterosexual love, which still forms the basis of it, is publicly, legally and economically institutionalised and celebrated. If anything, the white, frilly, punitively-expensive and highly public heterosexual wedding is on the ascendancy.

By contrast, gay love has not entered the public realm, richly and proudly conceived. There is no shortage of positive symbols of heterosexual love in the public sphere of life - in schools, in churches, in Parliament; but not so with gay symbols. Immanuel Kant thought of intimate relations outside of heterosexual marriage as a source of shame; it entailed a loss of human dignity. There is good evidence that our modern Anglian law still expresses this sentiment, in a variety of ways. It is there in marriage law; in criminal law; in civil law.

New Zealand seems to have gone a long way to change this. There have been extensive public discussions about the need to enlarge the public rights of gay persons and a new Act to formalise that enlarged set of rights. But as Graeme Austin observes, the denial of the right to marry is "most

27 P D Baron "In the Name of the Father: the Paternal Function, Sexuality, Law and Citizenship" (2006) 37 VUWLR 307.

29 On the public nature of family life see Frances Olsen "The Family and the Market: A Study of Ideology and Legal Reform" (1983) 96 Harv L Rev 7. 
obviously and profoundly a denial of equal access to the symbolic resources from which people can construct who they are." ${ }^{30}$ And the public shame is still there. Within Parliament and the judiciary there is little sense of enthusiasm for sexual relations and family forms which depart from the traditional model, let alone a desire to celebrate them.

Full admission to a polity not only entails a grant of formal public rights. It also entails a strong symbolic dimension. To be fully admitted, one must be allowed to express and affirm, in a public manner, those aspects of one's identity that matter most. ${ }^{31}$ Heterosexual persons already have sexual citizenship in both senses. They possess a way of affirming their particular form of sexual intimacy in a highly public way, as well as a broad range of public institutions reflecting and endorsing the heterosexual order. ${ }^{32}$ The homosexual person is still excluded from this form of sexual citizenship and so is excluded from both a full and rich sense of national identity and also from all of the rights that accrue to citizens simply because they are heterosexual.

30 Austin, above n 2, 186.

31 See Kathleen A Lahey Are We Persons Yet? Law and Sexuality in Canada (University of Toronto Press, Toronto, 1999) for the Canadian case for full sexual citizenship for gay persons.

32 On the heterosexual order see Margaret Davies "Taking the Inside Out: Sex and Gender in the Legal Subject" in Ngaire Naffine and Rosemary Owens (eds) Sexing the Subject of Law (Law Book Company, Sydney, 1997) 3. 
